\title{
PENGARUH BERDIRINYA KOPERASI TERHADAP PEREKONOMIAN PENGURUS DAN ANGGOTA KOPERASI CAHAYA UMA HASTI DI DEPOK
}

\author{
Sugeng Haryono ${ }^{1}$, Nurlaela ${ }^{2}$ \\ ${ }^{1}$ Program Studi Informatika, ${ }^{2}$ Program Studi Teknik Industri \\ Fakultas Teknik dan Ilmu Komputer, Universitas Indraprasta PGRI \\ Email: Nurlaela2315@gmail.com ; Sugeng.unindra@gmail.com. \\ Diterima: 30 Maret 2020; Direvisi: 25 Juli 2020; dipublikasikan: 28 Agustus 2020
}

\begin{abstract}
ABSTRAK
Tujuan penelitian untuk mengetahui 1). Prospek volume usaha Koperasi Cahaya Uma Hasti dari tahun 2015-2018. 2). Prospek Sisa Hasil Usaha (SHU) Koperasi Cahaya Uma Hasti dari tahun 2015-2018. Penelitian ini dilakukan dengan menggunakan metode survei korelasional, sedangkan analisis yang digunakan untuk menguji kebenaran hipotesis dilakukan dengan analisis regresi linier sederhana. Sampel diambil dari pengurus dan Anggota Koprasi Cahaya Uma Hasti di Depok yang berjumlah 50 orang. Hasil penelitian menunjukkan bahwa terdapat pengaruh yang signifikan berdirinya koperasi (X) terhadap Perekonomian Pengurus dan anggota (Y), sebesar 21\%, sisanya (79\%) karena pengaruh faktor lain. Hal ini dibuktikan dengan nilai $\mathbf{S i g}=0.001<0,05$ dan $\mathbf{F}_{\text {hitung }}=$ 13.349.
\end{abstract}

Kata Kunci : Koperasi, Perekonomian Pengurus dan Anggota, Depok

\begin{abstract}
The purpose of this research is to find out 1). Prospects of the business volume of the Cahaya Uma Hasti Cooperative from 2015-2018. 2). Prospect of Remaining Operations (SHU) of Cahaya Uma Hasti Cooperative from 2015-2018. This research was conducted using the correlational survey method,while the analysis used to test the truth of the hypothesis is done by simple linear regression analysis. Samples were taken from the management and 50 members of Uma Hasti Light Koprasi in Depok. The results showed that there was a significant influence of the establishment of cooperatives $(X)$ on the Economy of Management and members $(Y)$, amounting to $21 \%$, the rest (79\%) due to the influence of other factors. This is evidenced by the value of Sig $=$ $0.001<0.05$ and Fcount $=13.349$.
\end{abstract}

Keywords: Cooperative, Economic Management and Members, Depok 


\section{PENDAHULUAN}

Dalam Undang-Undang Dasar 1945 khususnya pasal 33 ayat 1 dinyatakan bahwa "perekonomian disusun sebagai usaha bersama berdasar atas asas kekeluargaan'. Menurut penjelasan pasal di atas bahwa bangun perusahaan yang cocok adalah koperasi karena di dalamnya mengutamakan kemakmuran anggota pada khususnya dan masyarakat pada umumnya. Bukan kemakmuran orang seorang. Dalam hal ini sebagai usaha bersama yang dijiwai oleh semangat kerjasama dan kekeluargaan. Koperasi diharapkan menjadi tiang utama atau sokoguru perekonomian nasional, tidak saja harus sejajar dengan pelaku ekonomi lainnya, yaitu BUMN dan swasta, melainkan harus memiliki peran yang lebih dominan dalam membangun ekonomi yang berwatak demokrasi. Jika melihat keberhasilan usaha koperasi, maka dengan segala keseksemaan kita perlu melihat kekuatan yang memnjadi kunci keberhasialan pengembangan usaha tersebut.

Dengan sikap demikian, kekuatannya dapat kita pupuk menjadi landasan kekuatan yang lebih besar dan kokoh untuk maju, sedangkan kelemahannya harus segera diperbaiki agar tidak terulang di masa yang akan datang. Keberhasilan usaha koperasi harus ditunjang oleh tersedianya sarana dan prasarana penunjang dengan berbagai keunggulan dan kemudahan untuk percepatan arus informasi, menyebabkan segala sumber daya yang dikelola oleh koperasi dapat berkompentisi, baik harga maupun kualitas barang dan jasa yang ditawarkan. Koperasi Cahaya Uma Hasti di Depok merupakan sebuah koperasi yang kebanyakan anggotanya adalah warga di daerah Depok. Berdasarkan hasil pengamatan sementara bahwa keberhasilan usaha yang dicapai oleh Koperasi Cahaya Uma Hasti di Depok setiap tahunnya terjadi penurunan dalam pembelian dan penjualan produk.

Tabel 1. Laporan Laba/Rugi

Koperasi Cahaya Uma Hasti

\begin{tabular}{lrrrr}
\hline \multicolumn{1}{c}{ Komponen } & \multicolumn{4}{c}{ Tahun } \\
& \multicolumn{1}{c}{2015} & \multicolumn{1}{c}{2016} & \multicolumn{1}{c}{2017} & \multicolumn{1}{c}{2018} \\
\hline Penjualan Bersih & 185000000 & 179000000 & 1775000000 & 166250000 \\
HPP & 145000000 & 139250000 & 135250000 & 133500000 \\
Laba Bruto & 40000000 & 39750000 & 34250000 & 32750000 \\
Beban Usaha & 25000000 & 25000000 & 25000000 & 25000000 \\
SHU & 15000000 & 14750000 & 9250000 & 7750000 \\
\hline
\end{tabular}

Hal ini disebabkan oleh banyaknya anggota koperasi yang kurang apdet tentang info dikoperasi, mengakibatkan kurangnya jumlah simpanan dari jumlah transaksi baik pembelian maupun penjualan serta sisa hasil usaha yang diperoleh koperasi

Sehubungan dengan hal tersebut di atas, penulis bermaksud mengadakan penelitian untuk mengetahui lebih mendalam tentang Prospek Keberhasilan Usaha Koperasi Cahaya Uma Hasti di Depok. Dengan tema Pengaruh berdirinya koperasi terhadap perekonomian pengurus dan Anggota Koperasi Cahaya Uma Hasti di Depok

Menurut UU No 25 Tahun 1992, Koperasi adalah badan usaha yang beranggotakan orangseorang atau badan hukum Koperasi dengan melandaskan kegiatannya berdasarkan prinsip Koperasi sekaligus sebagai gerakan ekonomi rakyat yang berdasar atas asas kekeluargaan (Menteri Koperasi dan Usaha Kecil Menengah Republik Indonesia, 1992).

Koperasi adalah badan hukum yang didirikan oleh orang perseorangan atau badan hukum Koperasi, untuk dengan pemisahan kekayaan para anggotanya sebagai modal menjalankan usaha, yang memenuhi aspirasi dan kebutuhan bersama di bidang ekonomi, sosial, dan budaya sesuai 
dengan nilai dan prinsip Koperasi.(Undang-Undang Republik Indonesia Nomor 17 Tahun 2012 Tentang Perkoperasian, 2012).

Dari pengertian di atas, adapun perbedaan UU No 25 Tahun 1992 dan UU No 17 Tahun 2012 ialah

1. Dalam UU No 25 Tahun 1992 menjabarkan pengertian koperasi sebagai badan usaha dan badan hukum yang beranggotakan orang-seorang, sedangkan UU No 17 Tahun 2012 menjabarkan pengertian koperasi sebagai badan hukum yang didirikan oleh orang perseorangan. Perbedaan di sini dapat terlihat dari pemilihan kata yang digunakan untuk mendeskripsikan koperasi yakni badan usaha dan badan hukum yang jelas memiliki makna yang berbeda. Yang mana badan usaha merupakan badan yang menguraikan falsafah, prinsip, dan landasan-landasan yang digunakan sebagai acuan dalam melakukan usaha, sedangkan badan hukum merupakan bagian dari badan usaha yang bersifat lebih mengingat dan ada sanksi yang tegas terhadap setiap pelanggaran. Dalam badan hukum juga terdapat persetujuan pemerintah atas penyelenggaraan suatu usaha.

2. Dilihat dari segi konsistensian kata (diksi kalimat/ pilihan kata) dalam pengertian koperasi menurut UU No 25 Tahun 1992, terjadi ketidakkonsistenan kata, yang dalam UU No 25 Tahun 1992 tidak hanya menguraikan pengertian koperasi sebagai badan usaha, tetapi pula sebagai badan hukum, sedangkan UU No 17 Tahun 2012 terjadi hal yang berlawanan,yakni adanya konsistenan kata yang digunakan untuk mendeskripsikan pengertian koperasi yakni penggunaan kata badan hukum.

3. Dilihat dari sudut kejelasan Modal Koperasi, definisi koperasi menurut UU No 17 Tahun 2012 lebih menguraikan lebih jelas komposisi modal yang dimiliki Koperasi. Hal tersebut dibuktikan dengan pernyataan mengenai pengertian koperasi sebagai badan hukum dengan pemisahan kekayaan para anggotanya sebagai modal menjalankan usaha. Melalui penjabaran yang lebih mendalam mengenai pemisahaan kekayaan ini, nantinya diharapkan tidak hanya untuk mempertegas komposisi modal, tetapi juga dapat memperjelas dan mempertegas bahwa modal yang digunakan koperasi bebas dari modal asing (modal anggota).

4. Dilihat dari prinsip koperasi yang dijabarkan dalam definisi koperasi. Prinsip Koperasi dalam UU No 17 Tahun 2012 menyatakan makna yang lebih luas (general), detail dan tegas pada peran penting koperasi pelayanan dibandingkan prinsip kopersai yang tertuang pada definisi koperasi dalam UU No 25 Tahun 1992. Hal tersebut dibuktikan dengan penjabaran prinsip koperasi menurut kedua UU tersebut.

Prinsip Koperasi dalam UU No 17 Tahun 2012 yang terdapat pada Pasal 6, yaitu:

1. Koperasi melaksanakan Prinsip Koperasi yang meliputi:

a. keanggotaan Koperasi bersifat sukarela dan terbuka;

b. pengawasan oleh Anggota diselenggarakan secara demokratis;

c. anggota berpartisipasi aktif dalam kegiatan ekonomi Koperasi;

2. Koperasi merupakan badan usaha swadaya yang otonom, dan independen;

3. Koperasi menyelenggarakan pendidikan dan pelatihan bagi Anggota, Pengawas, Pengurus, dan karyawannya, serta memberikan informasi kepada masyarakat tentang jati diri, kegiatan, dan kemanfaatan Koperasi;

Menurut Hendar, (2010) koperasi merupakan organisasi otonom dari orang-orang yang berhimpun secara sukarela untuk memenuhi kebutuhan dan aspirasi ekonomi, sosial dan budaya secara bersama-sama melalui kegiatan usaha yang dimiliki dan dikendalikan secara demokratis. 
Sedangkan menurut Revrisond Baswir, (2013), Koperasi adalah suatu bentuk perusahaan yang didirikan oleh orang-orang tertentu, untukmelaksanakan kegiatan-kegiatan tertentu, berdasarkan ketentuan dan tujuan tertentu pula.

Dari bebarapa pengertian yang terdapat di perundang-undangan dan pendapat ahli dapat disimpulkan bahwa koperasi merupakan salah satu badan usaha yang didirikan oleh orang-perorang secara sukarela yang memiliki kesamaan tujuan dengan pengelolaan secara demokratis dan berdasarkan asas kekeluargaan. Kepemilikan pada koperasi adalah sama tidak dipengaruhi besar atau kecilnya modal yang disetor, ini yang membedakan antara koperasi dengan badan usaha lainnya, yaitu Perseroan Terbatas (PT).

Menurut (Ayuk \& Utama, 2011), Koperasi merupakan salah satu kekuatan ekonomi yang mendorong tumbuhnya perekonomian nasional. Sisa Hasil Usaha (SHU) Koperasi juga menjadi salah satu elemen penting dalam meningkatkan kesejahteraan para anggota, termasuk pada Koperasi Simpan Pinjam (KSP) di Kabupaten Badung. Tujuan penelitian ini adalah sebagai berikut : 1) Untuk mengetahui pengaruh jumlah anggota, jumlah simpanan anggota, jumlah pinjaman anggota dan jumlah modal kerja secara simultan terhadap Sisa Hasil Usaha (SHU) Koperasi Simpan Pinjam (KSP) di Kabupaten Badung; 2) Untuk mengetahui pengaruh jumlah anggota, jumlah simpanan anggota, jumlah pinjaman anggota dan jumlah modal kerja secara parsial terhadap Sisa Hasil Usaha (SHU) Koperasi Simpan Pinjam ( KSP) di Kabupaten Badung; 3) Untuk mengetahui variabel yang paling dominan berpengaruh di antara varibel jumlah anggota, jumlah simpanan anggota, jumlah pinjaman anggota dan jumlah modal kerja terhadap Sisa Hasil Usaha (SHU) koperasi Simpan Pinjam ( KSP) di Kabupaten Badung. Penelitian ini mengambil lokasi di Kabupaten Badung. Data dikumpulkan dengan teknik random sampling, dengan menganalisis 34 koperasi dari 46 koperasi simpan pinjam di Kabupaten Badung dari tahun 2007-2011. Analisis data dilakukan dengan metode regresi linear berganda. Hasil analisis data diketahui bahwa jumlah anggota, jumlah simpanan, jumlah pinjaman dan jumlah modal kerja secara simultan berpengaruh signifikan terhadap sisa hasil usaha koperasi simpan pinjam di Kabupaten Badung. Variabel jumlah anggota, dan jumlah modal kerja secara parsial berpengaruh positif dan signifikan terhadap sisa hasil usaha koperasi simpan pinjam di Kabupaten Badung, sedangkan variabel jumlah simpanan dan jumlah pinjaman tidak berpengaruh. Variabel jumlah modal kerja berpengaruh paling dominan terhadap sisa hasil usaha koperasi simpan pinjam di Kabupaten Badung. Berdasarkan hasil penelitian disarankan perlunya upaya untuk memperkecil bunga pinjaman dan biaya administrasi, karena akan mempengaruhi perilaku anggota koperasi dalam melakukan pinjaman di unit usaha simpan pinjam koperasi. Jika bunga pinjaman dan biaya administrasi diperkecil, anggota akan lebih tertarik melakukan pinjaman, sehingga penerimaan unit usaha simpan pinjam menjadi bertambah dan pada akhirnya tingkat partisipasi anggota menjadi lebih besar

Wirawati, Ngakan Putu Teja ;Hadinata, (2016) Koperasi berfungsi sebagai lembaga ekonomi yang mencari keuntungan untuk menyejahterakan para anggota pada khususnya, serta masyarakat sekitar pada umumnya. Peran dan manfaat koperasi di Indonesia sangatlah penting, karena koperasi membuka pintu gerbang Usaha Kecil dan Menengah (UKM), menciptakan masyarakat yang mandiri, penggerak perekonomian hingga menciptakan lapangan kerja baru. Penelitian dilakukan pada Koperasi Pasar Srinadi Klungkung Tahun 2012-2014.Sampel penelitian ini adalah laporan keuangan masing-masing unit usaha pada Koperasi Pasar Srinadi Klungkung yang berjumlah 11 unit usaha pada tahun 2012-2014 yang dipilih dengan metode nonprobability sampling.Pengumpulan data berupa dokumentasi.Teknik analisis yang digunakan adalah regresi linear berganda. Berdasarkan hasil analisis diketahui bahwa tingkat perputaran kas dan perputaran 


\section{Sosio e-kons}

Volume 12, No. 2, Agustus 2020, pp. 115-124

e-ISSN: 2502-5449

p-ISSN: 2085-2266

DOI : $10.30998 /$ sosioekons.v12i02.6260

piutang berpengaruh positif signifikan terhadap rentabilitas ekonomi, sedangkan tingkat likuiditas dan pertumbuhan koperasi tidak berpengaruh signifikan terhadap rentabilitas ekonomi.

Menurut Kumara \& Saputra, 2014, Koperasi adalah badan hukum yang menjalankan usaha dengan tujuan meningkatkan kesejahteraan anggota dan masyarakat sekitarnya. Pemanfaatan koperasi secara maksimal dan optimal akan dapat menciptakan perekonomian nasional yang selaras dengan pertumbuhan koperasi. Penelitian ini bertujuan untuk mengetahui bagaimana pengaruh antara perputaran aktiva lancar, perputaran aktiva tetap, perputaran total aktiva, dan perputaran modal kerja terhadap profitabilitas. Penelitian dilakukan pada Koperasi Serba Usaha di Kecamatan Penebel Tahun 2010-2012. Teknik analisis yang digunakan adalah regresi linear berganda. Berdasarkan hasil uji hipotesis ditemukan bahwa secara parsial perputaran aktiva lancar berpengaruh negatif signifikan terhadap profitabilitas, perputaran total aktiva berpengaruh positif signifikan terhadap profitabilitas, dan perputaran modal kerja berpengaruh negatif signifikan terhadap profitabilitas.

\section{METODE}

Penelitian ini dilakukan dengan menggunakan metode survei korelasional, sedangkan analisis yang digunakan untuk menguji kebenaran hipotesis dilakukan dengan analisis regresi linier sederhana. Ada dua variabel yang diteliti, yaitu terdiri dua variabel bebas Koperasi dan satu variabel terikat yakni Perekonomian anggota dan pengurus. Adapun bentuk desain penelitian dapat dilihat dalam gambar berikut ini.

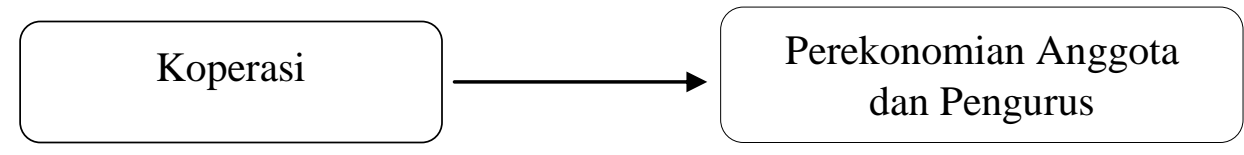

\section{Gambar 1. Konstelasi Masalah}

Populasi target adalah keseluruhan subjek penelitian secara teori yang banyaknya tidak terjangkau atau terbilang. Oleh karena itu, yang menjadi target dalam penelitian ini adalah pengurus dan Anggota Koperasi Cahaya Uma Hasti di Depok. Sampel diambil dari pengurus dan Anggota Koperasi Cahaya Uma Hasti di Depok. Yang berjumlah 50 orang. Sampel Hal ini berdasarkan pendapat Arikunto (2008:166), mengemukakan bahwa, "untuk memenuhi persyaratan penelitian apabila subjek kurang dari 100, maka lebih baik diambil semua, sehingga penelitiannya merupakan penelitian populasi. Selanjutnya jika subjeknya besar dapat diambil antara 10\% - 15\% atau $20 \%$ - $25 \%$ atau lebih."

Merujuk pada pendapat Arikunto di atas, sampel pada penelitian ini penulis mengambil secara acak populasi sebanyak 50 orang, dengan asumsi bahwa sampel sudah cukup terwakili dan data cukup heterogen, sehingga dengan pengambilan sampel sebanyak ini dapat dianggap telah memenuhi persyaratan dalam penelitian ini.

Sumber data untuk variabel bebas (berdirinya Koprasi dan satu variabel terikat yakni peningkatan volume perekonomian anggota dan pengurus koperasi) data diambil dari wawancara dan volume penjualan produk serta SHU 2015-2018 


\section{Sosio e-kons}

Volume 12, No. 2, Agustus 2020, pp. 115-124

e-ISSN: 2502-5449

p-ISSN: 2085-2266

DOI : $10.30998 /$ sosioekons.v12i02.6260

\section{HASIL DAN PEMBAHASAN}

\section{Hasil}

Dalam deskripsi data penelitian ini akan dikemukakan berbagai hasil penelitian dari data yang diperoleh yang meliputi: skor tertinggi, skor terendah, rerata (mean), modus, median, ragam/varians dan simpangan baku/standar deviasi. Dari hasil pengukuran pengaruh koprasi terhadap perekonomian anggota dan karyawan koprasi. 50 orang yang dijadikan sampel penelitian. Dalam pengolahan data yang diperoleh, penulis melakukan pengolahan data dengan bantuan Microsoft Office Excel 2010 dan SPSS 20 dengan hasil sebagai berikut:

\section{Tabel 2. Deskriptif Statistik}

\begin{tabular}{|l|r|r|}
\hline \multicolumn{1}{|c|}{ Statistics } \\
\hline Valid & MoPRASI & $\begin{array}{r}\text { PEREKONOM } \\
\text { IAN }\end{array}$ \\
\hline Mean & 50 & 50 \\
Median & 0 & 0 \\
Mode & 86.26 & 98.00 \\
Std. Deviation & 86.00 & 97.50 \\
Skewness & $85^{\mathrm{a}}$ & 99 \\
Std. Error of Skewness & 3.238 & 7.540 \\
Kurtosis & .377 & 1.053 \\
Std. Error of Kurtosis & .337 & .337 \\
Minimum & .662 & 1.563 \\
Maximum & 80 & .662 \\
a. Multiple modes exist. The smallest value is \\
shown
\end{tabular}

\section{Deskripsi Data Pengaruh berdirinya koprasi}

Data pengaruh berdirinya koperasi diperoleh skor maksimum sebesar 94, minimum sebesar 80, mean sebesar 86,26, media 86.00, modus sebesar 85, standar deviasi sebesar 3,238.

Dari deskripsi tersebut juga dapat dilihat bahwa nilai rata-rata dan median hampir sama, yaitu 86,26 dan 86,00. Hal ini menunjukkan bahwa data skor Marketing Mix pada penelitian ini cukup representatif. Deskripsi data dapat dilihat dari Histogram pada gambar 2.

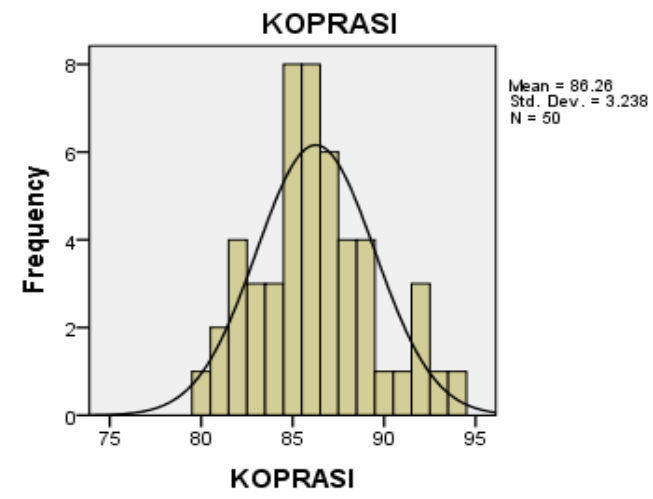

Gambar 2. Histogram Berdirinya Koperasi 


\section{Sosio e-kons}

Volume 12, No. 2, Agustus 2020, pp. 115-124

e-ISSN: 2502-5449

p-ISSN: 2085-2266

DOI : $10.30998 /$ sosioekons.v12i02.6260

Dari histogram dan poligon frekuensi di atas dapat disimpulkan bahwa data tingkat berdirinya koperasi dalam penelitian ini memiliki sebaran yang cendrung normal, karena bentuk dari kurva mendekati bentuk normal.

\section{Deskripsi data perekonomian pengurus dan anggota}

Pada pengukuran aspek peningkatan volume penjualan pengusaha garam, diperoleh skor maksimum sebesar 86, minimum sebesar 119, mean sebesar 98,00, median97,50, modus 99, standar deviasi sebesar 7,540.

Dari deskripsi tersebut juga dapat dilihat bahwa nilai rata-rata dan median hampir sama, yaitu 98,00 dan 97,50. Hal ini menunjukkan bahwa data peningkatan volume penjualan pada penelitian ini cukup representatif. Deskripsi data dapat dilihat dari Histogram pada gambar 3

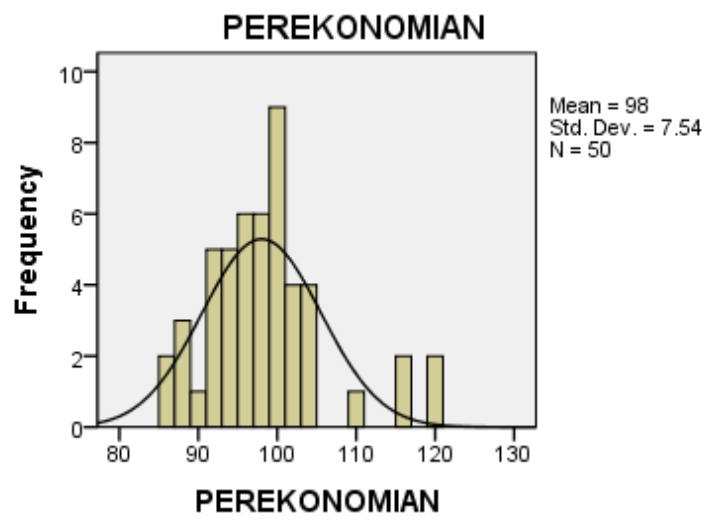

\section{Gambar 3. Histogram Peningkatan Volume Penjualan}

Dari histogram dan poligon frekuensi diatas dapat disimpulkan bahwa peningkatan volume penjualan dalam penelitian ini memiliki sebaran yang cendrung normal. Karena bentuk dari kurva mendekati bentuk normal.

Hasil perhitungan dan pengujian bisa dilihat pada tabel di bawah ini:

Tabel 3. Hasil Perhitungan Koefisien Korelasi Pengaruh Variabel X terhadap Variabel Y Model Summary

\begin{tabular}{ccccc}
\hline Model & R & R Square & $\begin{array}{c}\text { Adjusted R } \\
\text { Square }\end{array}$ & $\begin{array}{c}\text { Std. Error of the } \\
\text { Estimate }\end{array}$ \\
\hline 1 & $.466^{\mathrm{a}}$ & .218 & .201 & 6.739 \\
\hline a. Predictors: (Constant), Koperasi & & &
\end{tabular}

Sumber: Aplikasi Statistik Praktis SPSS 20 
Tabel 4. Rekapitulasi Hasil Perhitungan Pengujian Signifikasi Koefisien Regresi Pengaruh Variabel X terhadap Variabel $Y$ ANOVA $^{\mathrm{a}}$

\begin{tabular}{llccccc}
\hline Model & & $\begin{array}{c}\text { Sum of } \\
\text { Squares }\end{array}$ & df & $\begin{array}{c}\text { Mean } \\
\text { Square }\end{array}$ & F & Sig. \\
\hline \multirow{2}{*}{1} & Regression & 606.215 & 1 & 606.215 & 13.349 & $.001^{\text {b }}$ \\
& Residual & 2179.785 & 48 & 45.412 & & \\
& Total & 2786.000 & 49 & & & \\
\hline
\end{tabular}

a. Dependent Variable: Perekonomian

b. Predictors: (Constant), Koperasi

Sumber: Aplikasi Statistik Praktis SPSS 20

Tabel 5. Pengaruh Variabel $X$ terhadap Variabel $Y$ Coefficients $^{\mathrm{a}}$

\begin{tabular}{rlrrrrr}
\hline & Model & \multicolumn{2}{c}{$\begin{array}{l}\text { Unstandardized } \\
\text { Coefficients }\end{array}$} & $\begin{array}{l}\text { Standardized } \\
\text { Coefficients } \\
\text { Beta }\end{array}$ & t & Sig. \\
& B & Std. Error & Beta & \\
\hline 1 & (Constant) & 4.287 & 25.667 & & .167 & .868 \\
& Koperasi & 1.086 & .297 & .466 & 3.654 & .001 \\
\hline
\end{tabular}

a. Dependent Variable: Perekonomian

Sumber: Aplikasi Statistik Praktis SPSS 20

\section{Pembahasan}

Pengaruh beridirinya Koperasi $(X)$ terhadap perekonomian anggota \& pengurus (Y)

Hipotesis yang diuji terdapat pengaruh beridirinya Koperasi terhadap perekonomian anggota \& pengurus. Dari tabel 5.6.di atas terlihat bahwa koefisien korelasi pengaruh variabel bebas beridirinya Koprasi (X) terhadap perekonomian anggota \& pengurus (Y) adalah sebesar 0,466.

Perhitungan pengujian signifikansi koefisien korelasi ini bisa dilihat di Lampiran Hipotesis. Dari perhitungan tersebut diperoleh bahwa koefisien korelasi tersebut signifikan, dengan kata lain bahwa terdapat pengaruh yang signifikan variabel konten pengaruh berdirinya Koperasi terhadap perekonomian anggota $\&$ pengurus .

Koefisien determinasinya sebesar 0,218 menunjukkan bahwa besarnya kontribusi pengaruh berdirinya Koperasi terhadap perekonomian anggota \& pengurus adalah sebesar $21 \%$, sisanya (79\%) karena pengaruh faktor lain. Untuk pengujian hipotesis melalui analisis regresi diperoleh hasil perhitungan terlihat pada Tabel 2. dan Tabel 3. Dari Tabel. 3. diperoleh persamaan garis regresi yang merepresentasikan pengaruh variabel Xterdahap variabel $\mathrm{Y}$, yaitu $\widehat{\boldsymbol{Y}}=4.287+1.086 \mathrm{X}$

Pengujian signifikansi garis regresi tersebut adalah dengan memperhatikan hasil perhitungan yang ada pada Tabel 2. Menurut ketentuan yang ada, kriteria signifikansi regresi tersebut adalah "jika Sig $<0.05$ maka $\mathrm{H}_{0}$ ditolak" atau "jika $\mathbf{F}_{\text {hitung }}>\mathbf{F}_{\text {tabel }}$ maka $\mathrm{H}_{0}$ ditolak", yang berarti bahwa koefisien regresi tersebut signifikan, dengan kata lain terdapat pengaruh yang signifikan variabel bebas X terhadap variabel terikat Y. Nilai Sig adalah bilangan yang tertera pada kolom Sig dalam Tabel -5.7. Nilai $\mathbf{F}_{\text {hitung }}$ adalah bilangan yang tertera pada kolom $\mathbf{F}$ dalam Tabel 2. Sedangkan nilai $\mathbf{F}_{\text {tabel }}$ adalah nilai tabel distribusi $\mathbf{F}$ untuk taraf nyata 5\% dengan derajat pembilang $(\mathrm{k})=2$ dan derajat penyebut $(\mathrm{n}-\mathrm{k}-1)=13$ dimana $\mathrm{n}$ adalah banyaknya responden, dan $\mathrm{k}$ adalah banyaknya variabel bebas. 
Dari Tabel 5 terlihat bahwa nilai $\mathbf{S i g}=0.001<0,05$ dan $\mathbf{F}_{\text {hitung }}=13.349$ maka $\mathrm{H}_{0}$ di tolak yang berarti bahwa koefisien regresi tersebut signifikan. Dengan kata lain bahwa terdapat pengaruh yang signifikan beridirinya koperasi $(\mathrm{X})$ terhadap Perekonomian anggota dan pengurus (Y).

Dari Output diatas dapat di ketahui nilai $t_{\text {hitung }}=3,654$ dengan nilai signifikansi $0,001<0,05$ maka $\mathrm{H}_{0}$ di tolak dan $\mathrm{H}_{1}$ diterima yang berarti terdapat pengaruh yang signifika beridirinya koprasi (X) terhadap Perekonomian angota dan pengurus (Y). Dari hasil pengujian regresi tersebut maka bisa disimpulkan bahwa terdapat pengaruh koperasi $(\mathrm{X})$ terhadap Perekonomian anggota dan pengurus (Y).

\section{SIMPULAN}

Berdasarkan deskripsi data penelitian dan setelah dilakukan analisis, penulis menyimpulkan, bahwa:

1. Terdapat pengaruh yang signifikan beridirinya koperasi $(\mathrm{X})$ terhadap Perekonomian anggota dan pengurus $(Y)$. Hal ini dibuktikan dengan nilai Sig $=0.001<0,05$ dan Fhitung $=13.349$.

2. Terdapat pengaruh yang signifikan beridirinya koperasi $(X)$ terhadap Perekonomian anggota dan pengurus (Y). Hal ini dibuktikan dengan nilai Sig=0,001 $<0,05$ dan Thitung $=3,654$

\section{SARAN}

Saran yang dapat penulis sampaikan pada kesempatan ini adalah sebagai berikut :

1. Ada beberapa hal mendasar yang sangat penting dalam upaya memajukan koperasi adalah dengan merekrut anggota yang berkompeten dalam bidangnya. Tidak hanya orang yang sekedar mau menjadi anggota melainkan orang-orang yang memiliki kemampuan dalam pengelolaan dan pengembangan koperasi. Contohnya dengan mencari pemimpin yang dapat memimpin dengan baik, kemudian pengelolaan dipegang oleh orang yang berkompeten dalam bidangnya masing-masing. Serta perlu dibuat pelatihan bagi pengurus koperasi yang belum berpengalaman.

2. Masyarakat atau anggota harus sadar dan mengerti akan pentingnya peran koperasi dalam perekonomian Indonesia. Koperasi tidak hanya berguna untuk melakukan simpan pinjam saja, akan tetapi juga dapat memberikan ilmu sebagai modal kita untuk membuka lapangan pekerjaan.

3. Perlu adanya suatu promosi untuk mengenalkan suatu produk atau jasa pada seseorang sehingga orang tersebut berminat menggunakan produk atau jasa tersebut. Koperasi juga termasuk dalam usaha keuangan, oleh karena itu juga perlu mengenalkannya pada masyarakat sehingga akan ada orang baru yang tertarik menjadi anggota. Jika anggota bertambah secara otomatis keuangan koperasi semakin banyak dan usaha semakin berkembang.

\section{DAFTAR RUJUKAN}

Ayuk, N. M. T., \& Utama, I. M. S. (2011). Pengaruh Jumlah Anggota, Jumlah Simpanan, Jumlah Pinjaman Dan Jumlah Modal Kerja Terhadap Sisa Hasil Usaha (Shu) Koperasi Simpan Pinjam (Ksp) Di Kabupaten Badung Provinsi Bali. E-Journal Universitas Udayana.

Arikunto. S. (2008). Prosedur Penelitian Suatu Pendekatan Praktis. Jakarta : Rineka Cipta. Hendar. (2010). Manajemen Perusahaan Koperasi. Erlangga

Kumara, D. P., \& Saputra, I. D. G. D. (2014). Pengaruh Efisiensi Modal Kerja Terhadap 


\section{Sosio e-kons}

Volume 12, No. 2, Agustus 2020, pp. 115-124

e-ISSN: 2502-5449

p-ISSN: 2085-2266

DOI : $10.30998 /$ sosioekons.v12i02.6260

Profitabilitas Koperasi Serba Usaha. E-Jurnal Akuntansi Universitas Udayana.

Menteri Koperasi dan Usaha Kecil Menengah Republik Indonesia. (1992). Undang-Undang Republik Indonesia Nomor 25 Tahun 1992. Tentang Perkoperasian, 1-28. https://doi.org/10.1590/s1809-98232013000400007

Revrisond Baswir. (2013). Koperasi Indonesia. Bpfe

Undang-Undang Republik Indonesia Nomor 17 Tahun 2012 Tentang Perkoperasian. (2012). Perkoperasian, 1-56. www.hukumonline.com

Wirawati, Ngakan Putu Teja;Hadinata, N. G. P. (2016). Pengaruh Tingkat Perputaran Kas, Perputaran Piutang, Likuiditas, Dan Pertumbuhan Koperasi Pada Rentabilitas Ekonomi. EJurnal Akuntansi Universitas Udayana. 